\title{
PJIEE
}

Premise : Journal of English Education and Applied Linguistics https://fkip.ummetro.ac.id/journal/index.php/english

Saputra

\section{AN ANALYSIS OF STUDENTS' SPEAKING ANXIETY TOWARD THEIR SPEAKING SKILL}

\author{
Juni Bayu Saputra \\ THE COLLEGE OF TEACHER TRAINING AND EDUCATION OF TUNAS \\ PALAPA \\ junibayu.albana@gmail.com
}

Accepted : January 1, 2018

Revised: January 19, 2018

Accepted: March 24, 2018

Published: April 2, 2018

\begin{abstract}
:
This article points out the results of the study attempting to analyze the students speaking anxiety at students in one of the College of Teacher Training and Education (STKIP) in Lampung. For the purpose of the topic, 28 fellow students were selected as the sample. Research method was quasi-experimental design with two way ANOVA. It was conducted for about four months. According to the results of speaking test, findings showed that using Communicative Language Teaching (CLT) had positive meaningful effect on improving students' speaking skill viewed from different speaking anxiety. To sum up, CLT is an effective method to teach students' speaking skill viewed from different speaking anxiety.
\end{abstract}

Key term: Speaking Anxiety, Communicative Language Teaching, Speaking Skill.

\section{INTRODUCTION}

During the process of EFL language learning in higher level, a great deal of students might face some problems. Language anxiety is one of those obstruction and it is a substantial concern that can be assumed as a psychological disorder, therefore anxiety is one of the most significant factors during EFL learning process, and it has been intended in this study to represent foreign language anxiety among language learners and to clarify in which ways anxiety may affect the achievement of the students' speaking skill. It also aims to demonstrate the types and causes of anxiety and how to recognize language anxiety and especially the anxiety of speaking skill. Furthermore it purposes to illustrate the reasons for anxiety of speaking skill applying to the qualitative survey technique in the whole preparation classes of STKIP Tunas Palapa. Furthermore, 
the survey results of the present study indicate that most of the students suffer from anxiety of oral performance because of self-related reasons while the rest of them complain about their peer-related and teacher-related causes of distress.

Anxiety a disturbing combination of emotions including fear, worry and difficulty, and is usually followed by physical reactions "such as high blood pressure, increased heart rate and other body signals" (p. 419). It is seen in literature that foreign language learning has a great importance especially since English nowadays has become internationally recognized and demand for learning English has increased day by day (Chen and Lee, 2011).

As foreign language learners, anxiety, especially foreign language speaking anxiety, has a great importance on students' talents specifically when they need to express their knowledge about a specific subject. Foreign Language Anxiety (FLA) in speaking skill is one element that many English as Foreign Language teachers (EFL teachers) do not focus much on. The idea of teaching the four basic skills of English, i.e. listening, speaking, reading and writing, was somewhat bound by the effort of transferring the knowledge and disregarding the students' anxieties in using English in the class.

The main reason was because anxiety itself is a complex matter since it involved psychological condition of the learners. Communication apprehension, described as "a type of shyness characterized by fear of or anxiety about communicating with people" (Horwitz et al., 1986,p.127), is experienced by anxious individuals in social interaction.

Anxious students feel uncomfortable when communicating in the L2 and the inability to express oneself may lead to frustration since their knowledge of the new language is limited and they cannot control the situation (Horwitz et al., 1986)

Oral communication consists of listening and speaking, and since the language classroom puts an emphasis on interactions, speaking is considered as one of the most anxiety provoking activities. Research has shown that communication apprehension is common among anxious students (Young, 1990).

Speaking is a productive skill like writing, it involves using speech to express meaning to other people. We can develop learners' speaking skills by focusing regularly on particular aspect of speaking, e.g. fluency, pronunciation, grammatical accuracy or body language (Spratt et.al, 2005, p. 34). Furthermore, speaking is one way to 
communicate with ideas through a message orally. To enable students to communicate, we need to apply the language in real communication. According to Rickheit \& Strohner (2008) speaking is speech or utterances with the purpose of having intention to be recognized by speaker and the receiver processes the statements in order to recognize their intentions (p. 207). In addition, Kayi (2006) says that teaching speaking is a very important part of second language learning. The ability to communicate in a second language clearly and efficiently contributes to the success of the learners in school and success later in their life. Thus, it is essential that language teacher pay great attention to the teaching of speaking (p. 1).

Speaking, as one of the English language skill has some aspects. According to Heaton (1988, p. 100) there are three aspects of speaking, they are: accuracy, fluency, and comprehensibility. However, based on the researcher's teaching experience in his classroom, he found many problems related to the teaching of speaking. Most of the students were in high level of speaking anxiety that made them were not really motivated in speaking task. Some of them knew how to construct sentences but they were reluctant to speak. They were afraid of making mistakes in pronouncing the words or English grammar. Besides, they were afraid of being laughed at by other students, so they just keep silent and bore their ideas and feeling in their mind. Harmer (2007) states that students are often reluctant to speak because they are shy and are not predisposed to expressing themselves in front of other people, especially when they are being asked to give personal information or opinion (p. 345).

The problem coming from the students as stated by Lucantoni (2002) is when students think that they are based on what they say. They then prefer keeping silent to speaking language (p. 48). In addition, Lucantoni (2002) proposes suggestions to solve the problems. First, provide students with the functional exponents they need in order to carry out pair work and role-play activities, and demonstrate exactly what they have to do. Then, put them in situation where they have to speak in English in order to complete a task. Secondly, always encourage - do not allow students to become discourage when they make mistakes. They have to understand that making mistakes is part of the learning process (p. 6).

Based on the discussion above, then the researcher try to make use of Communicative Teaching Learning (CLT) to solve the existing problem. It is because 
during learning process of CLT, students' are hoped to communicate orally and conquer all components of communicative competence and teacher is being motivator, assessor, facilitator, and corrector during students' discussion or speaking in front of the class. In addition, the teacher also should make their lesson interesting so the students don't fall asleep during learning English (Harmer, 1998, p. 1). Learning activities in CLT focuses on real oral communication with variety of language without too focus on form of grammatical patterns if distinguished with non-communicative activities which only focus on how to construct the sentences that based on terms of grammatical during learning process of English (Harmer, 1998, p. 85).

CLT itself started in the late 1960s and continues to evolve. It is not actually a method but an approach to teaching based on the view that learning a language means learning how to communicate effectively in the world outside the classroom. It developed mainly as a reaction to the limitations of previous methods which put little, if any, emphasis on the ability to communicate or interact. It was also influenced by developments in the way the language was described - taking into account the communicative function of language, i.e. that we use language to do things like suggest, invite, agree, request, criticize, predict, and so on (Richards and Rodgers, 2001, p. 153).

Communicative approach in language teaching starts from a theory of language as communication. The goal of language teaching is to develop communicative competence (Richard and Rodger, 1999, p. 69).

CLT appeared at a time when British language teaching was ready for a paradigm shift. Situational Language Teaching was no longer felt to reflect a methodology appropriate for the seventies and beyond. CLT appealed to those who sought a more humanistic approach to teaching, one in which the interactive processes of communication received priority. The rapid adoption and implementation of the communicative approach also resulted from the fact that it quickly assumed the status of orthodoxy in British language teaching circles, receiving the sanction and support of leading British applied linguists, language specialists, publishers, as well as institutions, such as the British Council (Richards, 1985).

CLT is the name which was given to a set of beliefs which included not only a reexamination of what aspect of language to teach, but also in a shift in emphasis in how to teach. The "what to teach" aspect of the communicative approach stressed 
the significance of language function rather than focusing solely on grammar and vocabulary. A guiding principle was to train students to use these language forms appropriately in variety of context and for a variety of purposes. The "how to teach aspect" of communicative approach is closely related to the idea that language learning will take care of its self and that plentiful exposure to language in use and plenty of opportunities to use it are vitally important for students' development and skill (Harmer, 1998, p. 84).

CLT can be understood as a set of principles about the goals of language teaching, how learners learn a language, the kinds of classroom activities that best facilitate learning, and the roles of teachers and learners in the classroom (Richards, 2006, p. 3 ).

CLT aims to make communicative competence as the goal of language teaching and to develop techniques and procedures for teaching language skills that are based on interdependent aspects of language and communication. Communicative competence includes grammatical competence, sociolinguistic, and strategies. Communicative language abilities include knowledge or competence and proficiency in the application of these competencies in the communicative use of language, contextual, and appropriate. Littlewood (1981) states, "One of the most characteristic features of CLT is that it pays systematic attention to functional as well as structural aspects of language." For others, it means using procedures where learners work in pairs or groups employing available language resources in problem-solving tasks (p. 1).

In relation with CLT to teach speaking, research has shown that CLT can be used to improve students' speaking skill (Saputra, 2015, Efrizal, 2012 and Wenjie, 2009).

Thus, based on its benefits for English learning and other good values of the use of CLT, in order to enrich the research, this study is then proposed to improve the speaking skill for the fellow students in one of STKIP Tunas Palapa viewed from different speaking anxiety.

\section{METHODOLOGY}

\section{Research design}

In this research, the researcher used experimental design because the purpose of this research is to investigate the influence of using CLT towards students' speaking 
skill viewed from different speaking anxiety. Fraenkel \& Wallen (1993) states that experimental research is one of the most powerful research methodologies the researcher can use. An experimental design is the general plan for carrying out a study with an active independent variable. Ary (2006) agreed that the design is important because it determines the study's internal validity, which is the ability to reach valid conclusions about the effect of the experimental treatment on the dependent variable. The researcher concluded that experimental design is a research that conducted to know or investigate the influence of a treatment. This design is important because it determines the study's internal validity to reach valid conclusions about the effect of the treatment. Therefore, the researcher used experimental design. It was a blueprint of the procedure that enabled the researcher to test her hypotheses by reaching valid conclusions about relationships between independent and dependent variables. It referred to the conceptual framework within which the experiment was conducted. Fraenkel and Wallen (1997, p. 112) state that the design of the research requires minimum of two independent variables, with at least two levels of each variable. The minimum design is called a two by two $(2 \mathrm{X} 2)$ factorial design. There are two main effects and two simple effects. The main effects are before and after the implementation of CLT. The simple effects are high speaking anxiety and low speaking anxiety.

\section{Research Population and Sample}

Population is any set of items, individuals, etc. that share some common and observable characteristics and from which a sample can be taken. Thus, one can speak of comparing test scores across a sample of a population of students (Richard \& Schmidt (2010,p.406). The population of this research is all students at the fifth semester of STKIP Tunas Palapa year academic 2017/2018.

After determining the population, a researcher should do the next plan that is determining the sample, because sample is any group of individuals that is selected to represent a population (Richard \& Schmidt, 2010,p. 465). In this research, the researcher takes clusters random sampling to take the sample. Cluster random sampling is the selection of groups or clusters, of subjects rather than individuals (Fraenkel \& Wallen, 1993, p. 84). At the end, the researcher got 28 students of PBing as the sample.

\section{Research Instrument}


In collecting the data, the researcher utilized some instruments such as questionnaire, and speaking tests. Questionnaire was used to obtain the data about students' speaking anxiety. Thus, speaking test was in the form of delivering speech test which is used for describing the students' speaking skill, the students' mean score, and the individual score after implementing the CLT. The inter-rater scoring system is used during the speaking test.

\section{DISCUSSION OF THE FINDINGS}

The result of the test focused mainly on the students' individual score, it indicated the ability of each student in speaking skill viewed from different speaking anxiety.

Multifactor analysis of Variance Test Hypothesis test is done after the results of the normality and homogeneity test are fulfilled. It is done to know whether the $\mathrm{H}_{0}$ (null hypothesis) is rejected or accepted. Multifactor analysis of variance is used to test the hypothesis. The $\mathrm{H}_{0}$ (null hypothesis) is accepted if $\mathrm{F}_{\mathrm{o}}$ is lower than $\mathrm{F}_{\mathrm{t}}$ and rejected if $\mathrm{F}_{\mathrm{o}}$ is higher than $F_{t}$. The mean scores can be seen in the following table.

Table 1. The Mean Scores of the Cells

\begin{tabular}{|c|c|c|c|}
\hline $\begin{array}{l}\text { Speaking skill } \\
\text { Speaking anxiety }\end{array}$ & Posttest (A1) & Pretest $\left(\mathbf{A}_{2}\right)$ & $\sum$ \\
\hline Low $\left(\mathbf{B}_{1}\right)$ & $\begin{array}{l}\text { Data }=14 \\
\sum X=1086 \\
\bar{X}=77.57\end{array}$ & $\begin{array}{l}\text { Data }=14 \\
\sum X=931 \\
\bar{X}=66.50\end{array}$ & $\begin{array}{l}\text { Data }=28 \\
\sum \mathbf{X}=\mathbf{2 0 1 7} \\
\bar{X}=\mathbf{7 2 . 0 4}\end{array}$ \\
\hline High $\left(\mathbf{B}_{2}\right)$ & $\begin{array}{l}\text { Data }=14 \\
\sum X=931 \\
\bar{X}=66.50\end{array}$ & $\begin{array}{l}\text { Data }=14 \\
\sum X=943 \\
\bar{X}=67.36\end{array}$ & $\begin{array}{l}\text { Data }=28 \\
\sum X=1874 \\
\bar{X}=66.93\end{array}$ \\
\hline$\sum$ & $\begin{array}{l}\text { Data }=28 \\
\sum \mathbf{X}=\mathbf{2 0 1 7} \\
\bar{X}=\mathbf{7 2 . 0 4}\end{array}$ & $\begin{array}{l}\text { Data }=28 \\
\sum X=1874 \\
\bar{X}=66.93\end{array}$ & $\begin{array}{l}\text { Data }=56 \\
\sum X=3891 \\
\bar{X}=\mathbf{6 9 . 4 8}\end{array}$ \\
\hline
\end{tabular}

Table 2. The Summary of Multifactor Analysis of Variance

\begin{tabular}{|c|c|c|c|c|c|c|}
\hline Source of Variance & SS & df & MS & $\mathbf{F}_{\mathbf{0}}$ & $F_{t(05)}$ & $\mathbf{F}_{\mathbf{t}(.01)}$ \\
\hline Between Columns & 365.1607 & 1 & 365.16071 & 7.32 & \multirow{6}{*}{4.03} & \multirow{6}{*}{7.15} \\
\hline Between Rows & 365.16 & 1 & 365.16071 & 7.32 & & \\
\hline Column by Row (Interaction) & 498.02 & 1 & 498.01786 & 9.98 & & \\
\hline Between Group & 1228.339 & 3 & 409.44643 & & & \\
\hline Within Group & 2593.643 & 52 & 49.877747 & & & \\
\hline Total & 3821.982 & 55 & & & & \\
\hline
\end{tabular}

Premise Journal Vol 7 No 1, April 2018, e-ISSN: 2442-482x, p-ISSN: 2089-3345, page 111-123 Copyright@2018 by PJEE 
Based on the table above, it can be concluded that:

1) Because $F_{o}$ between columns (7.32) is higher than $F_{t}$ at the level of significance $\alpha$ $=0.05$ (4.03) and $\alpha=0.01$ (7.15), the difference between columns is significant. Therefore, the null hypothesis $\left(\mathrm{H}_{0}\right)$ stating that there is no any difference on students' speaking skill before and after the implementation of CLT is rejected. The mean of students' score taught using discussion technique (72.04) is higher than those who are taught using role-play technique (66.93). It can be concluded that the use of discussion technique gives significant result on students' speaking skill.

2) Because $F_{o}$ between rows (7.32) is higher than $F_{t}$ at the level of significance $\alpha=$ 0.05 (4.03) and $\alpha=0.01$ (7.15), the difference between rows is significant. Therefore, the null hypothesis $\left(\mathrm{H}_{0}\right)$ stating that Students having low speaking anxiety $\left(\mathrm{B}_{1}\right)$ do not have better speaking skill than those having high speaking anxiety $\left(\mathrm{B}_{2}\right)$ is rejected. In addition, the mean score of students who have low speaking anxiety (72.04) is higher than those who have high speaking anxiety (66.93). It can be concluded that students having low speaking anxiety have better speaking skill than those having high speaking anxiety.

3) Because $F_{o}$ interaction (9.98) is higher than $F_{t}$ at the level of significance $\alpha=0.05$ (4.03) and $\alpha=0.01$ (7.15), there is an interaction effect between teaching technique and speaking anxiety toward students' speaking skill. Therefore, the null hypothesis $\left(\mathrm{H}_{0}\right)$ stating that there is no any interaction between the teaching technique, speaking skill and students' speaking anxiety is rejected. It means that the effect of teaching technique depends on the degree of students' speaking anxiety.

The findings of the research reveal that there is an interaction between teaching technique and students' speaking anxiety on the students' speaking skill.

Appropriate teaching techniques can give a significant effect on the students' speaking skill. One of appropriate teaching techniques is CLT. CLT could motivate the students to be active and had a great participation in speaking activity during teaching and learning process in classroom. Since the classroom is a community where learners learn through collaboration and sharing (Saputra, 2015). 
Besides teaching techniques, there are many things that have to be taken into consideration. One of those things is students' speaking anxiety. Speaking anxiety can influence students' speaking skill. Students with low level of anxiety will be very suitable with the implementation of CLT in the classroom by considering their characteristics that are confident and more active. As stated by Horwitz (2001), if the students are very anxious in class, they are probably not actively involved in teaching learning process. Foreign language anxiety has been found to have potential negative effects on academic achievement, cognitive processes, the social context, and the reaction for the language learner. It means students with low level of anxiety tend to be more active and often get involved in the class. They will practice speaking with no doubt. It indicates that the students with low speaking anxiety are more appropriate to be taught by using discussion technique.

Students with high level of anxiety tend to be less confident and stay silent in the class rather than those having low anxiety. They are afraid of making mistakes, getting feedback from the teacher or their friends, and also scared of procuring negative evaluation. All those fears guide them into passive performance. People with high levels of trait anxiety are often quite easily stressed and anxious. Students in this case will talk less and give the control to the teacher. However, although there are some kind of anxiety which give bad contribution to students learning, there can be a good kind of anxiety, that is facilitating anxiety which can give positive effect on students learning. Thus, the teachers' real job would be to help students keep adequate anxiety, neither too high nor too low, because a proper level of anxiety plays a positive role and can motivate students to maintain their efforts in learning.

Logically, students with low level of anxiety will have better speaking performance than students having high speaking anxiety. However, it is not totally right. When students are able to control their anxiety, their speaking skill will not be influenced. To manage students' speaking anxiety, the implementation of teaching technique will be very helpful. Based on the research findings, it is known that the score of speaking skill in posttest is significantly different from the score of speaking skill in pretest to the students having low speaking anxiety but the implementation of the technique is equal for teaching speaking to the students having high speaking anxiety; however, based on the result of ANOVA, the score of students having high speaking 
anxiety in speaking skill in pretest is still better than those who are in posttest. It means that, there is an interaction between teaching technique and students' speaking anxiety on the students' speaking skill.

\section{Summary}

Based on the data analysis and the results of the questionnaire, the researcher concludes that the research findings for the fifth students of STKIP Tunas Palapa are as follows:

1) There is difference on students' speaking skill before and after the implementation of CLT.

2) Students having low speaking anxiety have better speaking skill than those having high speaking anxiety.

3) There is interaction between the teaching technique, speaking skill and students' speaking anxiety.

Based on the research finding above, it can be concluded that the implementation of CLT is effective to teach speaking for the students of STKIP Tunas Palapa in academic year of 2017/2018. The effectiveness is affected by student's speaking anxiety. Therefore, there is an interaction between teaching technique (CLT) and students' speaking anxiety in teaching speaking skill for the students of STKIP Tunas Palapa.

\section{Suggestion}

Regarding this condition, teachers/lecturers can use CLT as the appropriate technique that hopefully can overcome the problem listed and improve the students' speaking skill. It is because learning activities in CLT focuses on real oral communication with variety of language without too focus on form of grammatical patterns. Furthermore, classroom activities are often designed to focus on completing tasks that are mediated through language or involve negotiation of information and information sharing. It enables students to be more comfortable, because the content is closely related to their real world that it will decrease their anxiety in making such failure and/or mistakes.

For the case of time, the researcher suggests that the higher school provides English subject per semester as local subject. By this way, students can get special 
treatment regarding to English skills that previously taught in integrated way. When fellow students get a specific class (un-integrated), they will get more time to learn about every skill in English.

\section{ACKNOWLEDGEMENT}

This study was funded by Yayasan Tunas Palapa No. 001/PT/YTP/2017 (grant number, Rp. 3.000.000).

All procedures performed in studies involving human participants were in accordance with the ethical standards of the institutional and/or national research committee and with the 1964 Helsinki declaration and its later amendments or comparable ethical standards.

\section{BIOPROFILE}

Juni Bayu Saputra is a head of English Education Study Program of STKIP Tunas Palapa Central Lampung. He obtained his undergrduate degree from Universitas Muhammadiyah Metro and his master's degree from Universitas Sebelas Maret (UNS) Solo. He is taking postgraduate study at the same university. His research interests are English Speaking, and Curriculum and Material Development. His corresponding email: junibayu.albana@gmail.com 


\section{REFERENCES}

Ary, Donald. (2008). Introduction to Research in Education. New York: Nelson Education Ltd.

Chen, C-M., Lee, T-H. (2011). Emotion Recognition and Communication for Reducing Second-Language Speaking Anxiety in a Web-Based One-to-One Synchronous Learning Environment. British Journal of Educational Technology, 42 (3), 417440.

Efrizal, Dedi. (2012). Improving Students' Speaking through Communicative Language Teaching Method at Mts Ja-alhaq, Sentot Ali Basa Islamic Boarding School of Bengkulu. International Journal of Humanities and Social Science Vol. 2 No. 20.

Fraenkel, E Jack \& Wallen, E Norman. (1993). How To Design and Evaluate Research in Education. Boston: Mc. Graw Hill.

Heaton, J.B. (1998). Writing English language Test. London : Long man.

Harmer, Jeremy. (2007). The Practice of English Language Teaching, (4 ${ }^{\text {th }}$ Edition). London: Pearson Longman.

Harmer, Jeremy. (1998). How to teach English: an introduction to the practice of English language teaching. New York: Longman.

Horwitz, E. K. (2001). Language anxiety and achievement. Annual Review of Applied Linguistics, 21, 112-126.

Kayi, H. (2006). Teaching Speaking: Activities to promote Speaking in a Second Language. (Online),TESL Journal, Vol XII, No.11.

Littlewood, W. (1981). Communicative Language Teaching. Cambridge: Cambridge University Press.

Lucantoni, P. (2002). Teaching and Assessing Skills in English as a Second Language. Cambridge: Cambridge University Press.

Richard, Jack C. (2006). Communicative Language Teaching Today. New York: Cambridge University Press.

Richards, J.C. \& Schmidt, R. (2010). Longman Dictionary of Language Teaching and Applied Linguistics. Fourth edition. Edinburgh Gate: Pearson Education Limited.

Rickheit, Gert \& Strohner, Hans (2008). Handbook of Communication Competence. Berlin: Mouten de Gruyter.

Saputra, Juni Bayu (2015). Communicative Language Teaching: Changing Students' 
Speaking Skill. Premise: Journal of English Education, Vol. 4, No. 1.

Spratt, M., Pulverness, A. \& Williams, M. (2005). The TKT (Teaching Knowledge Test) Course, United Kingdom: Cambridge University Press.

Wenjie, Cai. (2009). Using Communicative Language Teaching (CLT) to Improve Speaking Ability of Chinese Non-English Major Students. University.

Young, Dolly. J. (1991). Creating a Low-Anxiety Classroom Environment: What Does Language Anxiety Research Suggest? The Modern Language Journal 75 (4): 426-39. 